\title{
Changes in blow-by and compression pressure of a diesel engine during a bench durability test
}

\begin{abstract}
This paper presents changes in the tightness of a combustion chamber during a 1200-hour bench durability test. The study was conducted on three four-cylinder turbocharged DI diesel engines with a capacity of $1.3 \mathrm{dm}^{3}$. The changes in the tightness were determined on the basis of the results of periodical measurements of the blow-by flow rate under different conditions of engine operation and measurements of maximum compression pressure in the cylinders. The results showed that the maximum compression pressure remained at the same level during a long period of engine operation, corresponding to a distance of $150000 \mathrm{~km}$ covered by a car. After that period, the pressure started to decrease (after a distance of $200000 \mathrm{~km}$, it had dropped by 10\%). The blow-by flow rate decreased in the initial period of engine operation and then it started to rise linearly at full engine load. The rate of increase depended on engine speed -it was the smallest at low speeds (20\% increase in the time range of 100-1200 hours, which corresponded to a distance of 16 000-192000 $\mathrm{km}$ covered by a car - at $1000 \mathrm{rpm}$ ), and the highest at $4000 \mathrm{rpm}$ (an increase of $70 \%$ in the same time range).
\end{abstract}

Keywords: diesel engine, ring pack, blow-by, compression pressure, wear

\section{Zmiany natężenia przedmuchów spalin i ciśnienia sprężania w silniku o zapłonie samoczynnym podczas stanowiskowej próby trwalościowej}

W artykule zaprezentowano wyniki badań zmian szczelności komory spalania podczas 1200-godzinnej stanowiskowej próby trwałościowej. Badania przeprowadzono na trzech egzemplarzach 4-cylindrowego, turbodoładowanego silnika o zapłonie samoczynnym z wtryskiem bezpośrednim i objętości skokowej 1,3 dm $\mathrm{dm}^{3}$. Zmiany szczelności przestrzeni roboczej silnika ustalone zostaty na podstawie okresowych pomiarów natężenia przedmuchów spalin w różnych warunkach pracy silnika oraz pomiarów maksymalnego ciśnienia sprężania w poszczególnych cylindrach. Wyniki badań wskazuja, że maksymalne ciśnienie sprężania przez dlugi okres pracy silnika, odpowiadajacy 150 tys. $\mathrm{km}$ przebiegu samochodu, nie ulega zmniejszeniu. Po tym okresie zaczyna spadać (spadek przy przebiegu 200 tys. $\mathrm{km}$ wynosit 10\%). Natężenie przedmuchów spalin $w$ pierwszym okresie eksploatacji silnika spada, po czym, przy pełnym obciąieniu silnika, zaczyna liniowo wzrastać, przy czym szybkość wzrostu zależy od prędkości obrotowej silnika - najwolniej przy matych prędkościach (wzrost o $20 \%$ przy 1000 obr/min, w zakresie od 100 do 1200 godzin pracy silnika w teście), a najszybciej przy prędkości znamionowej $4000 \mathrm{obr} / \mathrm{min}$ (wzrost o $70 \%$ ).

Słowa kluczowe: silnik o ZS, uszczelnienie pierścieniowe, natężenie przedmuchów spalin, ciśnienie sprężania, zużycie

\section{Introduction}

The tightness of the combustion chamber is an important characteristic which determines the technical condition of an internal combustion engine. During engine operation, tightness deteriorates mainly due to wear on the pistonrings-cylinder assembly, as well as to the valves and valve seats. The decrease in tightness affects engine performance, fuel and oil consumption, and toxic emissions. In addition, increased blow-by, resulting from leakage, accelerates the degradation of the engine oil and, as a consequence, the wear of engine components. In the case of diesel engines, decreased tightness also impairs the start-up performance of a cold engine $[1,6,7]$.

Engine constructors endeavour to maintain - despite the inevitable wear of components - the tightness of the combustion chamber at the highest level for a long period of an engine's life. Deterioration of the above parameters, resulting from the decrease in the tightness of the combustion chamber, is often the reason for deeming an engine to be defective and thus withdrawing it from operation $[4,7]$.

\section{Wprowadzenie}

Szczelność komory spalania jest ważną cechą decydującą o stanie technicznym silnika spalinowego. Szczelność ta w czasie eksploatacji silnika pogarsza się głównie na skutek zużycia elementów zespołu tłok-pierścienie tłokowe-cylinder oraz zużycia zaworów i gniazd zaworowych. Spadek szczelności negatywnie wpływa na osiągi silnika, zużycie paliwa i oleju silnikowego oraz emisję związków toksycznych. Ponadto zwiększone przedmuchy spalin, będące skutkiem spadku szczelności, przyspieszają degradację oleju silnikowego, a w konsekwencji zużycie elementów silnika. W przypadku silników diesla spadek szczelności obniża również zdolności rozruchowe zimnego silnika [1, 6, 7].

Konstruktorzy silników dokładają starań, aby pomimo nieuniknionego zużycia jego elementów, szczelność komory spalania utrzymywała się na jak najwyższym poziomie przez długi okres eksploatacji silnika. Pogorszenie ww. parametrów, będące skutkiem spadku szczelności komory spalania, często jest powodem uznania silnika za niesprawny i podjęcia decyzji o jego wycofaniu z eksploatacji $[4,7]$. 
Assessments of the tightness of the combustion chamber usually take into account results of measurements of the flow rate of the blow-by as well as tests of maximum cylinder compression pressure [6]. Knowledge of changes of these parameters during the operation of an engine facilitates the evaluation of the structure of the engine, especially in terms of its durability. It is also helpful in assessing the usefulness of selected measurements for evaluation of the technical condition of the engine.

This paper presents results of tests of tightness of the combustion chamber of a compression-ignition engine during long-term test-stand durability evaluations. Knowledge of the rate of changes in the tightness as a function of engine operating time allows validation of results obtained in simulation studies of changes in the tightness of the combustion chamber using an analytical model of the piston ring pack $[2,3,8]$.

\section{Engine and method}

The test object was a 4-cylinder, turbocharged diesel engine with a capacity of $1.3 \mathrm{dm}^{3}$, with intercooling and exhaust gas recirculation. According to the technical specification, the maximum power of the engine was $55 \mathrm{~kW}$ at $4000 \mathrm{rpm}$, and maximum torque was $190 \mathrm{~N} \cdot \mathrm{m}$ at $1750 \mathrm{rpm}$. The engine had four valves per cylinder and common-rail fuel injection with direct fuel injection into the cylinder. The engine had a cast-iron cylinder block with a nominal diameter of 69.6 $\mathrm{mm}$. Piston travel was $82 \mathrm{~mm}$. The engine's ring assembly consisted of three rings: the rectangular first compression ring with a barrel chrome face, the tapered second compression ring, and the double bevelled oil ring with chrome faces and a coil spring. The aluminium piston had a cast iron insert under the first compression ring.

The tests were conducted on three engines at an engine test bench. Prior to testing proper, the engines were subjected to a four-hour run-in. Each of the engines then underwent a long-term durability test, during which they operated under heavy load conditions, in accordance with the elementary cycle (Fig. 1). During the test, the cycle was repeated 336 times. Before, during and after the durability test, about every 42 elementary cycles, speed characteristics and other measurements were performed to determine the parameters of the engine. The total time of operation of each engine during testing was about 1200 hours.

The blow-by flow rate was measured using an AVL4040-A02 Blow-by Meter during engine performance measurements both at full and at a low engine load (torque of $15 \mathrm{~N} \cdot \mathrm{m}$ ). The maximum compression pressure in each cylinder was measured using an SPCS-50 compression pressure tester.

\section{Results}

The results of the measurements of the maximum compression pressure in the cylinders of all of the engines tested are shown in Fig. 2. Figures 3 and 4 show speed characteristics of the blow-by flow rate averaged for the three test engines and obtained at full and low engine load at different periods of the durability test.
Do oceny szczelności komory spalania najczęściej wykorzystuje się wyniki pomiarów natężenia przedmuchów spalin do skrzyni korbowej oraz pomiarów maksymalnego ciśnienia sprężania w cylindrach [6]. Znajomość zmian tych parametrów w czasie eksploatacji silnika pozwala ocenić konstrukcję silnika, głównie pod względem trwałościowym. Jest również przydatna przy ocenie użyteczności wybranych pomiarów do oceny stanu technicznego silnika.

W prezentowanym artykule przedstawiono wyniki badań szczelności komory spalania silnika o zapłonie samoczynnym w trakcie długotrwałej stanowiskowej próby trwałościowej. Znajomość szybkości zmian szczelności w funkcji czasu pracy silnika pozwoli na ocenę poprawności wyników uzyskiwanych w symulacyjnych badaniach zmian szczelności komory spalania z wykorzystaniem analitycznego modelu uszczelnienia pierścieniowego [2, 3, 8].

\section{Obiekt i metoda badań}

Obiektem badań był 4-cylindrowy, turbodoładowany silnik ZS o objętości skokowej $1,3 \mathrm{dm}^{3} \mathrm{z}$ chłodzeniem powietrza doładowującego i recyrkulacją spalin. Wg specyfikacji technicznej moc maksymalna silnika wynosiła $55 \mathrm{~kW}$ i uzyskiwana była przy $4000 \mathrm{obr} / \mathrm{min}$, a maksymalny moment obrotowy wynosił $190 \mathrm{~N} \cdot \mathrm{m}$ przy $1750 \mathrm{obr} / \mathrm{min}$. Silnik posiadał 4 zawory na cylinder, układ wtryskowy typu Common Rail z bezpośrednim wtryskiem paliwa do cylindra. Silnik posiadał żeliwny blok z cylindrami o nominalnej średnicy 69,6 mm. Skok tłoka wynosił $82 \mathrm{~mm}$. Układ pierścieniowy silnika składał się z trzech pierścieni: prostokątnego pierwszego pierścienia uszczelniającego $\mathrm{z}$ baryłkową, chromowaną powierzchnią czołową, stożkowego drugiego pierścienia uszczelniającego oraz dwuwargowego pierścienia zgarniającego z chromowanymi powierzchniami czołowymi i ze sprężyną spiralną. Aluminiowy tłok posiadał żeliwną wkładkę pod pierwszy pierścień uszczelniający.

Badania przeprowadzono na trzech egzemplarzach silnika na hamowni silnikowej. Przed zasadniczymi badaniami silniki poddano 4 godzinnemu docieraniu. Następnie na każdym z silników przeprowadzono długotrwały test trwałościowy, podczas którego silnik pracował w warunkach dużych obciążeń wg elementarnego cyklu (rys. 1). W

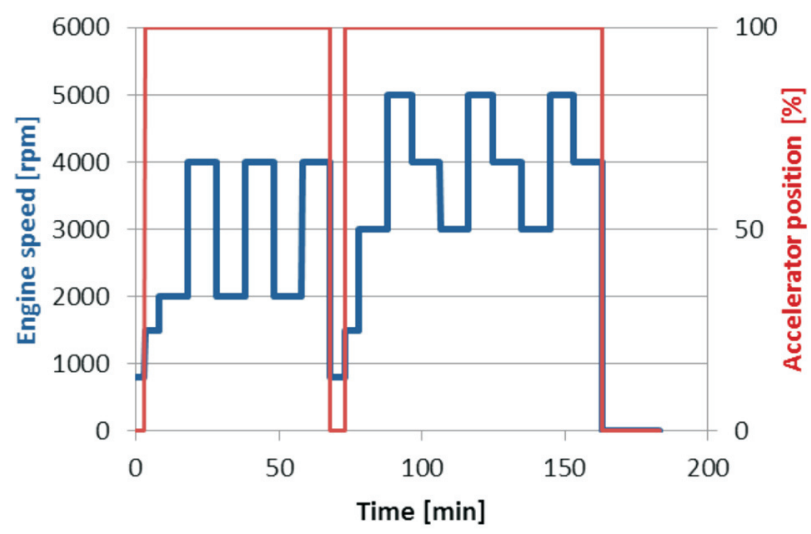

Fig. 1. Elementary cycle of the durability test Rys. 1. Pojedynczy cykl testu trwałościowego 


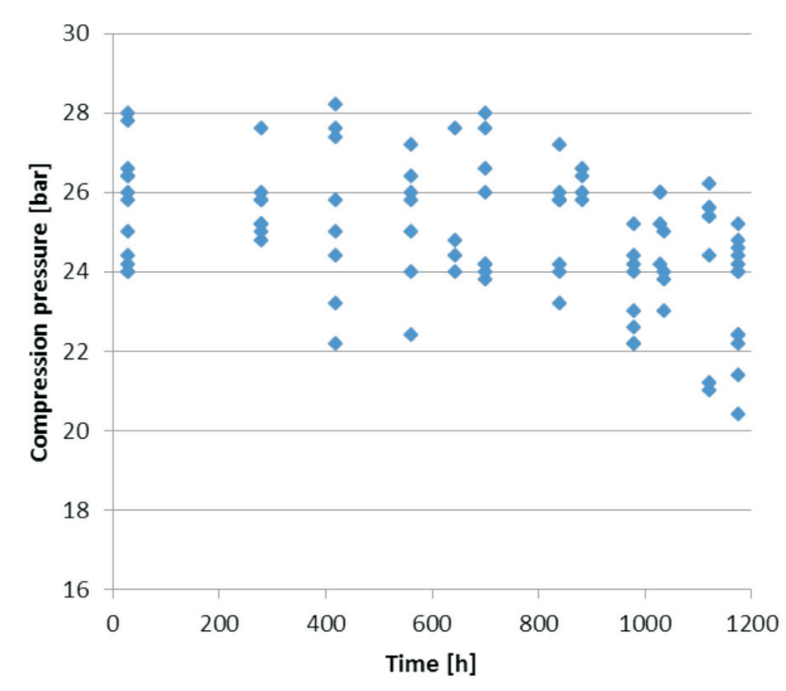

Fig. 2. Results of maximum compression pressure measurements Rys. 2. Wyniki pomiarów maksymalnego ciśnienia sprężania

Blow-by flow rate curves as a function of rotational speed at full and low engine load differed. At full load (Fig. 3 ), the blow-by flow rate was the highest at medium values of engine speed and it decreased along with the increase in engine speed (the shape is similar to the engine torque curve). However, at low engine load, the blow-by flow rate increased with increasing engine speed (Fig. 4).

Although the aforementioned curves of speed characteristics of blow-by flow rates did not significantly change during the test, the overall assessment of changes in the blow-by flow rate as a function of engine operation time based on them was difficult, because the curves for different times of engine operation did not change their position on the graph relative to one another in a regular way. For that reason, a decision was taken to analyse the results obtained in differ-

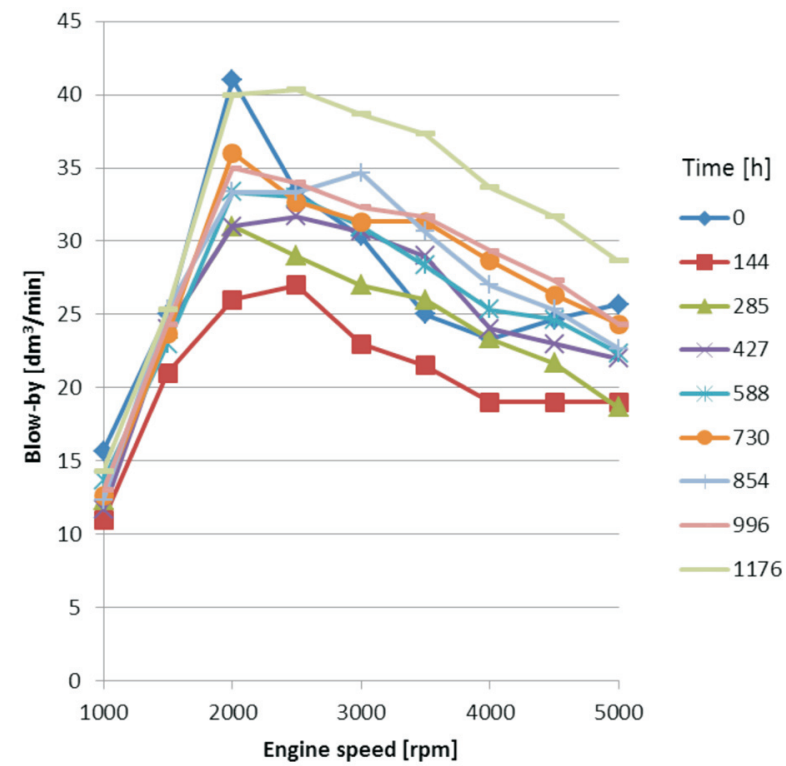

Fig. 3. Blow-by rate as a function of engine rotational speed at full load Rys. 3. Charakterystyki prędkościowe natężenia przedmuchów spalin przy petnym obciązeniu silnika czasie testu cykl ten był powtarzany 336 razy. Przed i po oraz w trakcie testu trwałościowego, co ok. 42 cykle elementarne, wykonywano charakterystyki prędkościowe oraz inne pomiary mające na celu ustalenie parametrów silnika. Łączny czas pracy każdego silnika podczas badań wynosił ok. 1200 godzin.

Natężenie przedmuchów spalin mierzono za pomocą przepływomierza AVL 4040-A02 Blow-by Meter podczas wykonywania charakterystyk prędkościowych pełnej mocy oraz przy małym obciążeniu silnika (moment obrotowy równy $15 \mathrm{~N} \cdot \mathrm{m}$ ). Maksymalne ciśnienie sprężania w poszczególnych cylindrach mierzono za pomocą próbnika ciśnienia sprężania SPCS-50.

\section{Wyniki badań}

Wyniki pomiarów maksymalnego ciśnienia sprężania w cylindrach wszystkich badanych silników przedstawiono na rys. 2 . Na rys. 3 i 4 przestawiono, uśrednione dla trzech badanych silników, charakterystyki prędkościowe natężenia przedmuchów spalin uzyskane przy pełnym i małym obciążeniu silnika w różnych okresach stanowiskowego testu trwałościowego.

Krzywe natężenia przedmuchów spalin w funkcji prędkości obrotowej przy pełnym i małym obciążeniu silnika miały różne kształty. Przy pełnym obciążeniu silnika (rys. 3) natężenie przedmuchów spalin było największe w zakresie średnich prędkości obrotowych silnika, a następnie wraz ze wzrostem prędkości malało (kształt zbliżony do kształtu krzywej momentu obrotowego silnika). Natomiast przy małym obciążeniu silnika natężenie przedmuchów spalin wzrastało wraz ze wzrostem prędkości obrotowej silnika (rys. 4).

Mimo, że wyżej opisane kształty charakterystyk prędkościowych natężenia przedmuchów spalin zasadniczo nie ulegały zmianie w czasie trwania testu, to całościowa ocena zmian natężenia przedmuchów spalin w funkcji czasu pracy

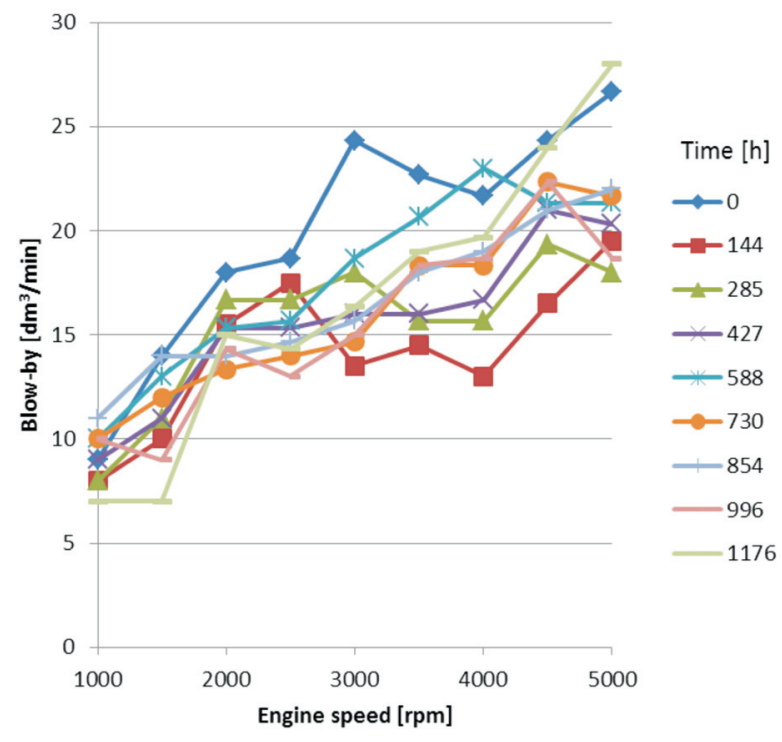

Fig. 4. Blow-by rate as a function of engine rotational speed at low engine load $(15 \mathrm{~N} \cdot \mathrm{m})$

Rys. 4. Charakterystyki prędkościowe natężenia przedmuchów spalin przy małym obciążeniu silnika $(15 \mathrm{~N} \cdot \mathrm{m})$ 
ent engine operating conditions separately, i.e. at a given rotational speed and load. Blow-by flow rates for different engine operation conditions as a function of testing time are shown in Figs. 5 and 6.

In all cases, the values of the blow-by flow rate obtained in measurements performed during the first hours of engine operation were higher than in the subsequent measurements performed after about 144 hours of engine operating (Figs. 5 and 6). The average decrease in the blow-by rate was $25 \%$. This decrease can be attributed to engine run-in. Unfortunately, due to the long period of operation between the first and the second measurement, the tests performed did not permit determination of the time after which the blow-by flow rate reached its minimum value. However, it is certain that the second measurement (after 144 hours of operation) was performed after engine run-in processes had been completed.

To assess whether and how the blow-by flow rate changed with the engine operating time after run-in, the subsequent analyses omitted the results obtained in the first measurement (during the first hours of engine operation). Calculations were made of linear correlation coefficients $r$ between the results of measurements of the blow-by flow rate and engine operation time. Also, the significance of the correlations was tested at a significance level of 0.05 [5]. The results indicated that there was a significant correlation between the blow-by flow rate and engine operating time at full engine load and that there was no such correlation for most of the rotational speeds at low engine load (at low load, the correlation was significant only at 2500, 3500 and $4500 \mathrm{rpm}$ ).

Because the linear correlations were considered significant at the assumed confidence level of 0.95 for all blow-by flow rates at full engine load, the corresponding regression

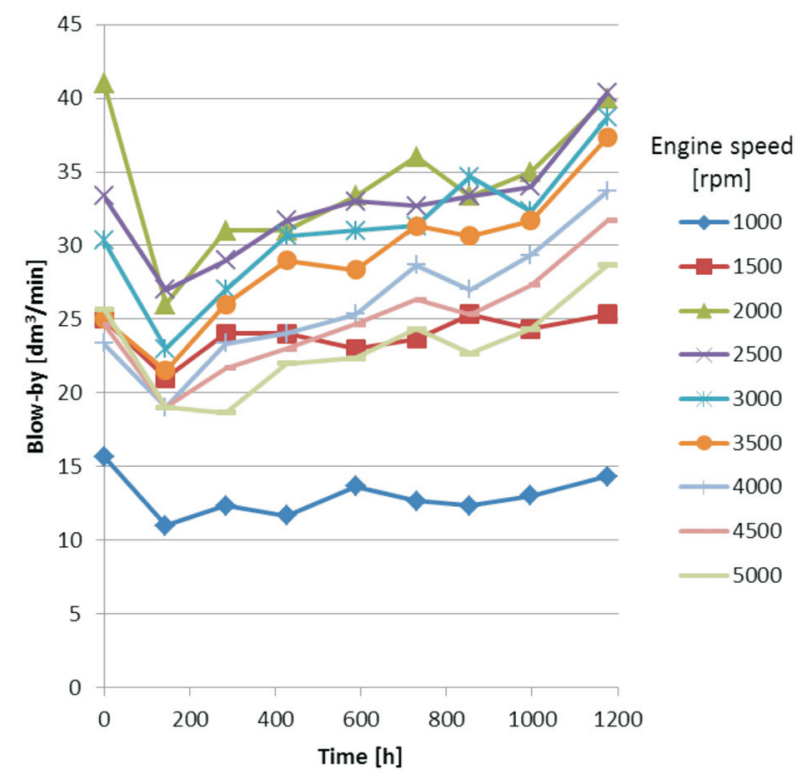

Fig. 5. Blow-by rate at full engine load as a function of engine operating time

Rys. 5. Natężenia przedmuchów spalin przy petnym obciążeniu silnika w funkcji czasu pracy silnika silnika w oparciu o nie była utrudniona, gdyż krzywe dla różnych czasów pracy silnika nie zmieniały swego położenia względem siebie na wykresie w sposób regularny. W związku z powyższym postanowiono odrębnie analizować wyniki uzyskane w różnych warunkach pracy silnika, tj. przy danej prędkości obrotowej i obciążeniu. Natężenia przedmuchów spalin dla różnych warunków pracy silnika w funkcji czasu trwania testu przedstawiono na rys. 5 i 6 .

We wszystkich przypadkach wartości natężenia przedmuchów spalin uzyskane w pomiarach wykonanych w pierwszych godzinach pracy silnika były większe, niż w następnych pomiarach wykonanych po ok. $144 \mathrm{~h}$ jego pracy (rys. 5 i 6). Średni spadek natężenia przedmuchów wyniósł $25 \%$. Spadek ten należy wiązać z docieraniem silnika. Niestety, ze względu na długi czas pracy silnika między pierwszym i drugim pomiarem, przeprowadzone badani nie pozwoliły na ustalenie czasu, po którym natężenie przedmuchów spalin osiągnęło wartość minimalną. Można natomiast stwierdzić, że drugi pomiar (po 144 h pracy silnika) został wykonany już po zakończeniu docierania silnika.

Aby ocenić, czy i jak natężenie przedmuchów spalin zmienia się wraz z czasem pracy silnika po zakończeniu procesów docierania, $w$ dalszych analizach pominięto wyniki uzyskane w pierwszym pomiarze (w pierwszych godzinach pracy silnika). Obliczono współczynniki korelacji liniowej r pomiędzy wynikami pomiarów natężenia przedmuchów spalin i czasem pracy silnika oraz zbadano istotność korelacji na poziomie istotności 0,05 [5]. Wyniki wskazywały na istotność korelacji natężenia przedmuchów spalin i czasu pracy w przypadku pełnego obciążenia silnika oraz brak korelacji, dla większości prędkości obrotowych, przy małych obciążeń silnika (przy małym obciążeniu korelacja była istotna tylko przy prędkościach obrotowych: 2500 , 3500 i $4500 \mathrm{obr} / \mathrm{min})$.

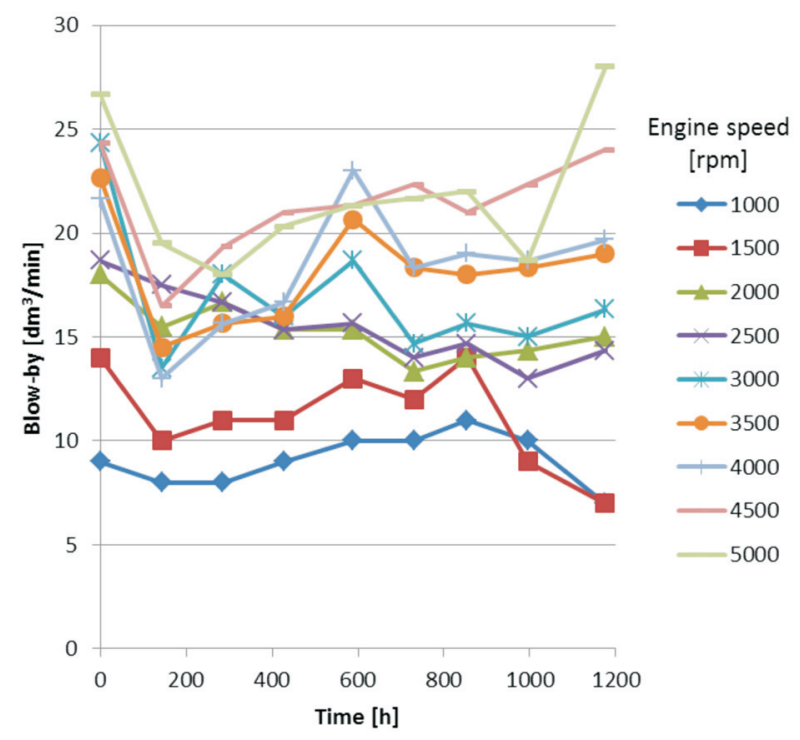

Fig. 6. Blow-by rate at small engine load as a function of engine operating time

Rys. 6. Natężenia przedmuchów spalin przy małym obciążeniu silnika w funkcji czasu pracy silnika 


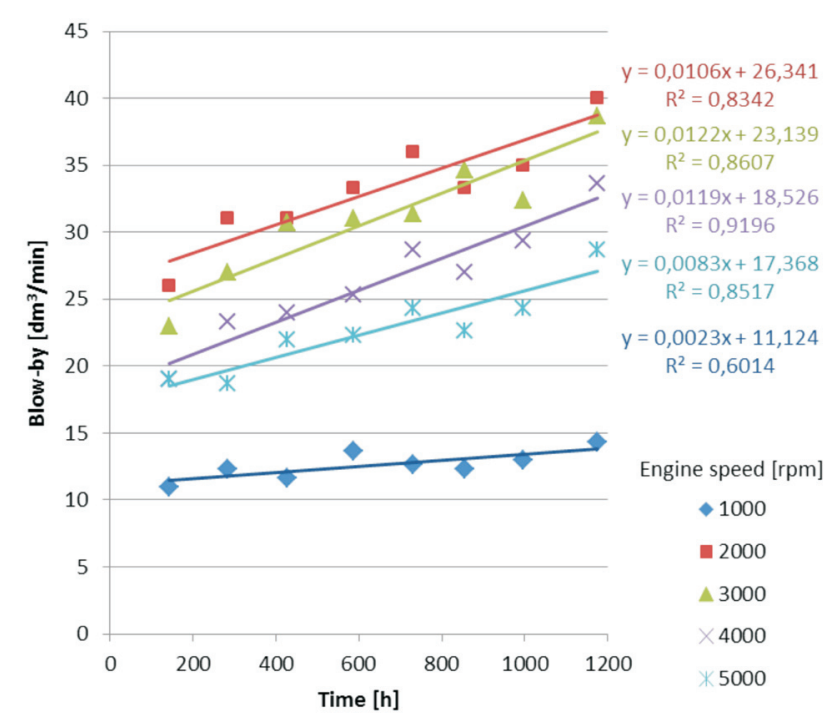

Fig. 7. Regression lines of blow-by rate at full engine load for completely run-in engines

Rys. 7. Proste regresji natężenia przedmuchów spalin przy petnym obciążeniu silnika dla w petni dotartych silników

lines were determined. Regression lines, are shown in Fig. 7, along with the corresponding equations and determination coefficient values $\mathrm{R}^{2}$.

At all of the rotational speeds of the engine analyzed and at full load, the blow-by flow rate increased with the engine operating time. However, the rate of this increase was different for different rotational speeds. The slowest increase with operating time was observed for blow-by at low rotational speeds of the engine - at $1000 \mathrm{rpm}$ there was an increase of $22 \%$ within the range of 100 to 1200 hours of operating time. Within the range of medium and high rotational speeds, these increases ranged from 40 to almost $70 \%$ (the highest increase occurred at a rotational speed of $4000 \mathrm{rpm})$.

To assess the impact of engine operation time on compression pressure, mean values were determined from measurements obtained from cylinders of all the engines at similar operation times (Fig. 8). The mean value of maximum compression pressure hardly changed up to about 900 hours of engine operation. After this time, there was a significant decrease in the maximum compression pressure. An attempt was also made to fit a suitable regression curve. Among the functions available in Excel, the best fit was obtained with the second-degree polynomial (Fig. 8).

The mean value of maximum compression pressure at the end of the durability test decreased by $9 \%$ relative to the first measurement carried out after $30 \mathrm{~h}$ of engine operation.

\section{Conclusions}

We analysed the results of measurements of the blow-by flow rate at full and low engine loads and of maximum compression pressure performed periodically on three engines during a prolonged durability bench test.

The maximum compression pressure during the durability test was unchanged for a long engine operating period;

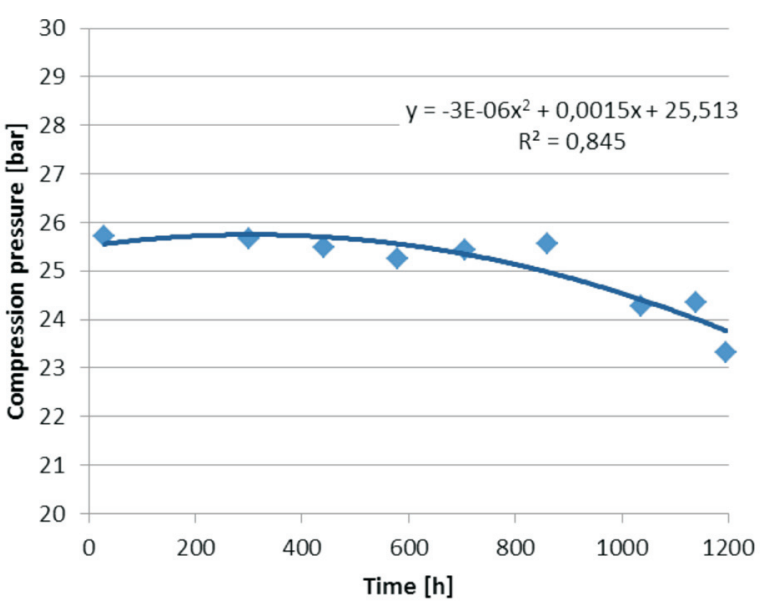

Fig. 8. Mean values of maximum compression pressure as a function of engine operation time

Rys. 8. Średnie wartości maksymalnego ciśnienia sprężania w funkcji czasu pracy silnika

Ponieważ we wszystkich przypadkach natężenia przedmuchu spalin przy pełnym obciążeniu silnika korelację liniową można uznać za istotną na przyjętym poziomie ufności 0,95 , wyznaczono odpowiednie proste regresji. Proste regresji wraz z odpowiednimi równaniami oraz wartościami współczynników determinacji $\mathrm{R}^{2}$ przedstawiono na rys. 7 .

Przy wszystkich analizowanych prędkościach obrotowych silnika i pełnym jego obciążeniu natężenie przedmuchów spalin wzrastało wraz z czasem pracy silnika. Jednak szybkość wzrostu była różna dla różnych prędkości obrotowych. Najwolniej wraz z czasem pracy wzrastały przedmuchy przy małych prędkościach obrotowych silnika - przy $1000 \mathrm{obr} / \mathrm{min}$ wzrost o $22 \% \mathrm{w}$ zakresie od 100 do 1200 h czasu pracy. W zakresie średnich i dużych prędkości obrotowych wzrosty te wynosiły od 40 do niemal $70 \%$ (największy wzrost przy prędkości obrotowej 4000 obr/min).

W celu oceny wpływu czasu pracy silnika na ciśnienie sprężania wyznaczono średnie wartości z pomiarów uzyskanych dla cylindrów wszystkich silników przy zbliżonych czasach ich pracy (rys. 8). Średnia wartość maksymalnego ciśnienia sprężania prawie nie zmieniała się do ok. 900. godziny czasu pracy silnika. Po przekroczeniu tego czasu nastąpił wyraźny spadek maksymalnego ciśnienia sprężania. Podjęto również próbę dopasowania odpowiedniej krzywej regresji. Spośród dostępnych w programie Excel funkcji, najlepsze dopasowanie uzyskano dla wielomianu drugiego stopnia (rys. 8).

Średnia wartość maksymalnego ciśnienia sprężania na koniec testu trwałościowego zmniejszyła się w stosunku do pierwszego pomiaru, przeprowadzonego po $30 \mathrm{~h}$ pracy silnika, o $9 \%$.

\section{Podsumowanie}

Przeanalizowano wyniki pomiarów natężenia przedmuchów spalin przy pełnym i małym obciążeniu silnika oraz maksymalnego ciśnienia sprężania wykonywanych okresowo na 3 silnikach podczas długotrwałej stanowiskowej próby trwałościowej. 
only after $900 \mathrm{~h}$ did it begin to drop. The decrease at the end of the test, i.e. after $1200 \mathrm{~h}$ of operation was $9 \%$. The manufacturer of the engine, based on past experience, assumes that one hour of engine operation in the durability test corresponds to $160 \mathrm{~km}$ of car mileage. This means that the maximum compression pressure did not change significantly up to a mileage of $150000 \mathrm{~km}$, while at $200000 \mathrm{~km}$ it decreased by $10 \%$.

In the first period of the durability test, the blow-by flow rate gradually decreased. After 150 hours of engine operation, it was about $25 \%$ lower than in the first hours of operation. After the first period of operation - the run-in period - the blow-by flow rate changes as a function of time depending on engine load.

At full engine load, blow-by flow rates increased in a linear manner along with engine operation time, and the rate of the increase depended on engine speed. The slowest increase in the blow-by flow rate along with operation time was observed at low speeds (at $1000 \mathrm{rpm}$, the increase was $20 \%$ at the end of the test, as compared to the state after 100 hours of engine operation), and the fastest increase occurred at $4000 \mathrm{rpm}$, i.e. the speed of the engine's rated power (an increase of almost $70 \%$, at the same operation time).

Surprising results were obtained for low engine loads, where at a confidence level of 0.95 , there was no significant correlation between the blow-by flow rate and engine operation time.

\section{Acknowledgments}

This work was partially financed by the National Research Centre within the framework of research project No. N N509 479538 .
Maksymalne ciśnienie sprężania przez długi okres pracy silnika podczas testu trwałościowego nie ulegało zmianie. Dopiero po $900 \mathrm{~h}$ pracy zaczęło spadać. Spadek ten na koniec testu, tj. po $1200 \mathrm{~h}$ pracy wynosił $9 \%$. Producent silników, w oparciu o wcześniejsze doświadczenia, przyjmuje, że jedna godzina pracy silnika $\mathrm{w}$ przeprowadzanym teście trwałościowym odpowiada $160 \mathrm{~km}$ przebiegu samochodu. Oznacza to, że maksymalne ciśnienie sprężania nie ulega istotnym zmianom do 150 tys. km przebiegu samochodu, a przy 200 tys. km spada o $10 \%$.

W pierwszym okresie testu trwałościowego natężenie przedmuchów spalin zmniejszało się. Po $150 \mathrm{~h}$ pracy silnika było ono o $25 \%$ mniejsze, niż w pierwszych godzinach jego pracy. Po pierwszym okresie pracy silnika - okresie docierania-zmiany natężenia przedmuchów spalin w funkcji czasu zależały od obciążenia silnika.

Przy pełnym obciążeniu silnika natężenie przedmuchów spalin liniowo wzrastało wraz z czasem jego pracy, przy czym szybkość wzrostu zależała od prędkości obrotowej silnika. Najwolniej wraz z czasem pracy wzrastały przedmuchy przy małych prędkościach obrotowych (przy $1000 \mathrm{obr} / \mathrm{min}$ wzrost o $20 \%$ na koniec testu, w stosunku do stanu po $100 \mathrm{~h}$ pracy silnika), a najszybciej przy prędkości $4000 \mathrm{obr} / \mathrm{min}$, czyli prędkości mocy znamionowej silnika (wzrost o niemal $70 \%$, w tym samym zakresie czasu pracy).

Zaskakujące wyniki uzyskano dla małych obciążeń silnika, gdzie na poziomie ufności 0,95 nie stwierdzono istotności korelacji pomiędzy natężeniem przedmuchów spalin, a czasem pracy silnika.

\section{Podziękowania}

Praca dofinansowana przez Narodowe Centrum Badań w ramach projektu badawczego Nr N N509 479538.

\section{Bibliography/Literatura}

[1] Kaźmierczak A.: Tarcie i zużycie zespołu tłok-pierścienie-cylinder. Oficyna Wydawnicza Politechniki Wrocławskiej, Seria Monografie 89 (32), Wrocław 2005.

[2] Koszałka G.: Application of the piston-rings-cylinder kit model in the evaluation of operational changes in blow-by flow rate. Eksploatacja i Niezawodnosc - Maintenance and Reliability, Vol. 48, No. 4, pp. 71-81, 2010.

[3] Koszałka G.: Predicting the durability of the piston-ringscylinder assembly of a diesel engine using a piston ring pack model. Eksploatacja i Niezawodnosc - Maintenance and Reliability, Vol. 51, No. 3, pp. 40-44, 2011.

Grzegorz Koszałka, DEng. - doctor in the Mechanical Engineering Faculty at Lublin University of Technology.

Dr inż. Grzegorz Koszatka - adiunkt na Wydziale Mechanicznym Politechniki Lubelskiej. e-mail: g.koszalka@pollub.pl
[4] Koszałka G., Suchecki A.: Durability prediction of a diesel engine piston-rings-cylinder assembly on the basis of test bench results. SAE Paper 2011-24-0130, 2011.

[5] Krysicki W. i in.: Rachunek prawdopodobieństwa i statystyka matematyczna w zadaniach - cz. II: Statystyka matematyczna. PWN, Warszawa 1994.

[6] Merkisz J., Tomaszewski F., Ignatow O.: Trwałość i diagnostyka węzła tłokowego silników spalinowych. Wydawnictwo Politechniki Poznańskiej, Poznań 1995.

[7] Niewczas A.: Trwałość zespołu tłok-pierścienie tłokowe-cylinder silnika spalinowego. WNT, Warszawa 1998.

[8] Wolff A.: Numerical analysis of piston ring pack operation. Combustion Engines 2(137), pp. 128-141, 2009.

Andrzej Suchecki, DEng. - Engine Testing Laboratory Manager at BOSMAL Automotive Research and Development Institute Ltd. of Bielsko-Biała. Drinż. Andrzej Suchecki-kierownik Pracowni Badań Stanowiskowych Silników w Instytucie Badań i Rozwoju Motoryzacji BOSMAL Sp. z o.o. w Bielsku-Biatej. e-mail: andrzej.suchecki@bosmal.com.pl

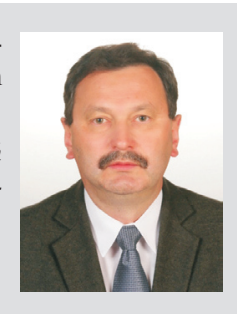

